\title{
Geneologi dan Gerakan Militansi Salafi Jihadi Kontemporer $^{1}$
}

\author{
Saeful Anwar \\ Institut Agama Islam Sunan Giri Bojonegoro \\ Email: saefulanwar712@gmail.com
}

\begin{abstract}
Abstrak: "Tulisan geneologi dan gerakan militansi salafi jihadi kontemporer ini, berusaha menjelaskan bagaimana suatu ide tertentu dalam salafi-jihadisme muncul, tipologi dan doktrin jihad salafism, dinamika gerakan jihad salafism dan karakteristik yang menentukannya. Tulisan ini juga akan menjelaskan cara yang unik dan berbeda yang mana para salafi-jihadis memahami, mengembangkan atau menterjemahkan ide-ide tersebut yang berbeda dengan bagaimana kelompok Muslim yang lain mempersepsikan ide tersebut melalui sebuah gerakan. Salafisme sendiri menurut penulis adalah sebuah konsep yang masih terlalu luas untuk dimaknai. Penulis mengutip perkataan Bernard Haykel bahwa Istilah salafi, dan hal-hal lain yang dikaitkan dengannya, masih belum didefinisikan dengan baik dan sering difahami secara salah dalam banyak literatur tentang pergerakan ini, dan dalam kajian Islam yang lebih umum. Dalam konstruksinya yang paling sederhana, salafisme Mengacu pada para pendahulu yang sholih dari tiga generasi awal Muslim. Karena itu salafisme adalah pandangan keagaaman yang menginginkan untuk menghidupkan kembali praktek-praktek tiga generasi awal Islam yang secara kolektif dikenal sebagai as-salafush shalihin. Penulis menjelaskan adanya banyak opini yang berbeda dari para ilmuwan tentang karakteristik tertentu yang secara presisi mendefinisikan gerakan salafi-jihadi sebagai sebuah kesatuan, yang merupakan salah satu bagian dari spektrum salafi yang luas. Dengan mengacu dan mengkompromikan pendapat yang berbeda dari para ilmuwan, penulis berpendapat bahwa ada lima ciri/fitur mendasar dari gerakan salafi-jihadi yaitu: tauhid, hakimiyyah, wala' wal baro', jihad, dan takfir. Kelima ciri ini dipilih berdasarkan arti pentingnya terhadap gerakan salafi-jihadi."
\end{abstract}

Keywords: Salafi, Tipologi, Jihadi Salafism dan Movement

\section{A. Pendahuluan}

Dinamika yang muncul diberbagai kawasan Islam sejak abad ke-19 sesungguhnya merefleksikan jawaban terhadap persoalan keagamaan, sosial, budaya, ekonomi politik yang dihadapi kaum muslimin. Beberapa kalangan tokoh muslim menyadari akan kondisi umat Islam yang secara objektif telah mengalami degradasi dalam kehidupan keagamaan, sosial, politik, dan budaya.sedangkan secara objektif melihat kenyataan telah berkembangnya

\footnotetext{
${ }^{1}$ Peper pernah dipresentasikan untuk memenuhi tugas mata kuliah Prof. Amin Abdullah: Metodologi Studi Islam pada hari Minggu tanggal 03 Desember 2017
} 
peradaban modern dari peradaban barat, yang berintikan sains dan teknologi modern. ${ }^{2}$ Kondisi yang berbeda antara masyarakat yang hidup di kawasan Islam dan non-Islam ini, jika dilihat dari mainstream keyakinan yang dianut oleh masing-masing masyarakat, pada akhirnya memunculkan ketidakseimbangan (disequilibirium) antara timur dan barat. $^{3}$ Ketidakseimbanagn ini kemudian diikuti oleh kuatnya dominasi politik barat dalam bentuk kolonialisme dan imperarialisme atas negara-negara yang mayoritas berpenduduk muslim. Meskipun dominasi politik ini secara fisik telah berakhir pada pertengahan abad ke-20, namun dominsai barat atas dunia Islam tetap berlanjut dan meluasa pada aspek sosial, ekonomi dan budaya. Lembaga-lembaga politik, ekonomi, dan budaya internasional ditenggarai menjadi alat yang sangat efektif untuk mempertahankan hegemoni barat dan timur (Islam), sampai dengan awal abad ke-21 ini.

Kondisi masyarakat muslim seperti digambarkan diatas mendorong munculnya respon yang beragam dari kalangan umat muslim sendiri. Kelompok salafi jihadi muncul secara ekstrimis sebagai kelompok yang munkin bisa dikatakan mewakili kelompok-kelompok eksklusif yang menolak dan ingin mengembalikkan dominasi barat pada tempatnya, ${ }^{4}$ dengan melakuklan aksi-aksi teror yang secara radikal tanpa mengenal kompromi seperti halnya serangan 11 semtember. Gerakan ini diidentikkan dengan radikalisme karena paham keagamaannya memiliki kemiripan dengan gerakan-gerakan Islam yang lain, sekaligus memiliki sumber yang sama. ${ }^{5}$

Salafisme muncul sebagai bentuk reformasi keagamaan radikal, yang bertujuan untuk menggantikan warisan keilmuan Islam tradisional. Tetapi, sementara reformasi agama telah lama menjadi fitur dunia Islam Modern, rumus Salafis bagi reformasi adalah retrograde. Hal ini menempatkan dirinya melawan semua arus agama lain di dalam dan di luar Islam, melawan arus politik dan intelektual, bersaing dengan liberalisme dan sekularisme, bahkan berseberangan dengan fondasi epistemologi yang mendasari modernitas.

\section{B. Geneologi dan Doktrin Salafi}

Kata Salafi adalah sebuah bentuk penisbatan al-salaf al-salih, ${ }^{6}$ yaitu tiga genarasi

\footnotetext{
${ }^{2}$ Ahmad Jaenuri, Radikalisme dan Terorisme, Akar Ideologi dan Tuntutan Aksi, Malang: Intrans Publishing, 2016, 1 
pertama Muslim yang dipandang sebagai uswah bagi masa depan umat Islam. Kata as-salaf secara bahasa juga bermakna orang-orang yang mendahului atau hidup sebelum zaman kita. ${ }^{7}$ Bernard Haykel mengemukakan bahwa Salafism mereferensi pada Ahl al-Hadith sejak masa kekhilafahan Abbasiyah, yang mengkosentrasikan pada studi hadis dengan maksud untuk membersihkan Islam dari campur tangan non-muslim. Sebagai gerakan pemurnian Islam, Salafism mengajarkan untuk kembali kepada sumber-sumber pokoknya, yakni al-Qur'an dan Hadis (termasuk tradisi/sunnah Nabi sebagai uswah hasanah yang merupakan penerjemahan nilai-nilai al-Qur'an), dan menolak taqlid kepada empat mazhab hukum Islam, dan karenanya menerima ijtihad. ${ }^{8}$ Salafism dengan demikian bukan saja skriptualis, tetapi juga literalis.

Tokoh-tokoh yang berkontribusi besar terhadap formasi Salafism sebagai doktrin adalah Ahmad bin Hanbal (780-855 M) dan Taqiy al-Din ibn Taymiyah (1263-1328 M), dan dipertegas dalam Wahhabism oleh Muhammad ibn 'Abd al- Wahhab (1703-1792 M). Wahhabism merupakan gerakan reformasi abad ke-18 di Najd, sentral Arab. ${ }^{9}$

Wahhabism menggunakan doktrin tawhid sebagai perisai isu politik, dengan menolak shari'ah dan taqlid. Selanjutnya,gan kontras terhadap Ibnu Hanbal, tetapi lebih condong kepada Ibn Taymiyah, Ibn 'Abd al-Wahhab bermaksud menyeru kepada semua orang yang tidak mengikuti doktrin tawhid sebagai kafir/kuffar atau murtaddun yang boleh diperangi dengan cara jihad kepada mereka. Kajian terbaru mencatat pelibasan tarhadap takhayul dan seruan reformasi (da'wah) sebagai esensi misi Wahhabi. ${ }^{10}$

Wahhabism bukan hanya gerakan revivalis yang mengerahkan energinya dari doktrin Salafi kasik. Di Yaman Muhammad ibn 'Ali al-Shawkani (w. 1834), seorang reformer, secara radikal mereorientasi sumber-sumber hukum dengan penggunaan secara langsung al-Qur'an dan Hadis, menghendaki ijtihad, membangun sebuah metode untuk mengimplementasikan reformasinya. ${ }^{11}$ Di India tokoh Wahhabi kontemporer, Shah wali Allah (1703-1762 M), meluncurkan program reformasi sejenis yang menolak taqlid dan kebiasaan umum, dan mengkonsentrasikan pada studi Hadis dan al-Qur'an. Hal yang sama diberikan oleh Mawlana Muhammad Ilyas (1885-1944), pendiri gerakan transnasional Tablihgi Jama'at di

al-tabi'in (sampai tahun $810 \mathrm{M}$ ) . Periode utama al-Salaf al-S|a>lih terbatas pada generasi pertama atau sampai pada masa al-Khulafa' al-Rashidun

${ }^{7}$ Abu al-Fadl Muhammad Ibnu Manzur: Qamus lisan al-Arab, Dar as- Shadir, Beirut, Lebanon 1410 H, Cet. Ke1, entri sa-la-fa, jilid 6, 330.

${ }^{8}$ Bernald Haykel, Revival and Reform in Islam: The Legacy of Muhammad al-Shawkani (Cambridge: Cambridge University Press, 2003).

${ }^{9}$ Roel Meijer, Global Salafism:Islam's New Religious Movement (London: C. Hurst Company, 2009), 4

${ }^{10}$ David Commins, The Wahabi Mission and Saudi Arabia (London: I.B. tauris, 2006), 14-17.

${ }^{11}$ Bernard Haykel, Revival and reform in Islam: The Legacy of Muhammad al-Shawkani, 76-108. 
India. Ia mengajarkan toleransi dan menolak kekerasan sebagaimana dalam program Jihad Wahhabi. Kedua tokoh tersebut menekankan tawhid dan menyatakan budaya lokal sebagai bid'ah, termasuk dalam hal ini adalah peringatan mawlid Nabi saw dan penyerapan ritual Hindu dan Shi'i kedalam praktek-praktek Sunni. ${ }^{12}$

Jika Wahhabism berbeda dengan gerakan-gerakan modern awal dalam bentuk dan kadarnya, maka ia berbeda dalam muatannya dengan gerakan-gerakan reformis Salafi pada akhir abad le-19 di Timur Tengah Arab yang dikibarkan oleh para pemikir semisal Muhammad 'Abduh (Mesir, 1849-1905), Jamal al-Din al-Afghani (Persi, 1839-1897), dan Rashid Rida (Syria, 1865-1935). Perbedaan dasarnya adalah yang pertama menekankan pada respons terhadap ancaman kultur, politik, dan ekonomi Barat tetapi menghargai Barat sebagai model. Sedang Wahhabism menekankan pada gerakan revivalis secara murni yang diarahkan pada purifikasi doktrin dan selanjutnya, ketika ia terbawa pada kontak dengan Barat, ia menolak Barat sebagai model, bahkan pada suatu saat, menolak teknologi Barat. Pada sisi lain, dengan pengecualian terhadap Rashid Rida, pengagum Wahhabism, mereka percaya bahwa kembali kepada sumber-sumber pokok Islam tidak bertentangan dengan penerimaan terhadap modelmodel Barat: pendidikan Barat, atau mempelajari bahasa Inggris dan bahasa Perancis.

Ada empat pokok doktrin Salafism yang diinspirasi dari Wahhabism. Pertama, program Wahhabism untuk kembali kepada sumber-sumber pokok Islam (al-Qur'an dan Hadis), sedang secara faktual mengikuti (taqlid) kepada Mazhab Hanbali. Hal ini memperlihatkan adanya kontradiksi. Reformer Nasir al-Din al-Albani (1914-1999), seorang yang paling berpengaruh terhadap Salafisme modern, adalah orang pertama untuk menggambarkan kontradiksi ini dalam Wahhabism. Stephane Lacroix menunjukkan bahwa al-Albani dipengaruhi oleh para reformer Salafi liberal akhir abad ke-19, yang menolak pemujaan kuburan shaykh dan taqlid, dan mempromosikan ijtihad. ${ }^{13}$ Akan tetapi al-Albani lebih radikal daripada para reformer tersebut dalam hal studi Hadis sebagai poin sentral gerakan reformisnya, yang mengarahkannya pada ilmu pengetahuan. ${ }^{14}$

Kedua, regulasi hubungan antara mukmin dan non-mukmin (outsider). ${ }^{15}$ Kontribusi

\footnotetext{
${ }^{12}$ Meijer, Global Salafism..., 6.

${ }^{13}$ Bernard Haykel, "Salafist Dotrine" dalam Meijer, Global Salafism .....,34-35.

${ }^{14}$ Lihat Stephane Lacroix, "Between Revolution and Apoliticsm: Nasir al-Din al-Albani and his Impact on the Shaping of the Contemporary Salafism” dalam Meijer, Global Salafism..., 58-80.

${ }^{15}$ Elit penguasa Arab dan Elit politik Amerika mempunyai hubungan yang erat, khususnya dari partai Republik. Banyak buku dan literatur tentang kedekatan keluarga kerajaan Saudi dengankeluarga Bush, sejak dari Presiden Bush Senior (George H) dan presiden Bush Yunior (Goerge W) yang menduduki kursi kepresidenan AS dalam dua priode terakhir. Begitu dekatnnya kedua belah pihak ini, sehingga muncul sebutan "House of Saud and House of Bush". Baca kata pengantar, Azyumardi Azra, Ekstrimisme Wahabi dan Islam Wasat\}iyah. Dalam
} 
Wahbabism terhadap Salafism adalah perlakuan keras terhadap orang asing dan sekte-sekte yang non-Wahhabi. Di sinilah muncul konsep ajaran al-Wala' wa al-Bara' (kesetiaan dan penolakan) atau antara mukmin dan non-mukmin. Wilayah yang non-Wahhabi disebut sebagai bilad al-mushrikin. Hal ini dapat digunakan untuk memahami perang dengan kerajaan Ottoman dan invasi ikhwan (pasukan khusus Wahhabi) ke Iraq. Ketiga, tema Wahhabi yang mempengaruhi Salafism dan telah menjadikannya radikal adalah penolakan terhadap Shi'ism sebagai bid'ah, dengan dua alasan: (1) Shi'is mengkultuskan imams dan (2) Shi'is menolak tiga diantara Khulafa' Rashidun (632-661) dan karenanya menolak para sahabat Nabi dan otentisitas Hadith yang merupakan basis ajaran Wahhabism/Salafism. ${ }^{16}$

Keempat, ambiguitas Wahhabism yang diwariskan kepada Salafism modern adalah pada praktek hisba, yakni al-amar bi al-ma'ruf wa al-nahy 'an al-munkar. Meskipun praktek ini berlangsung lama dan telah eksis sejak masa Dinasti Abbasiyah (750-1258) dan dinyatakan oleh Ibn Taymiyah sebagai bentuk puncak jihad, hal tersebut dipertahankan oleh Wahhabism untuk menegaskan sikap moral kerasnya tehadap masyarakat dan meluruskan deviasi seperti merokok, memuja tempat keramat, dan bentuk-bentuk lain yang termasuk shirk. Pada tahun 1920-an praktek hisba dilembagakan oleh polisi agama (mutawwa'/mutawwi'a) untuk memaksa moralitas masyarakat dan pelaksanaan salat tepat waktu. Pada tahun 1950-an Komite Amar Ma'ruf Nahi Munkar juga digunakan sebagai alat politis untuk menolak oposisi sekular.

\section{Jihadi Salafisme dan Tipologinya}

Penulis menjelaskan adanya banyak opini yang berbeda dari para ilmuwan tentang karakteristik tertentu yang secara presisi mendefinisikan gerakan jihadi salafisme sebagai sebuah kesatuan, yang merupakan salah satu bagian dari spektrum salafi yang luas. Dengan mengacu dan mengkompromikan pendapat yang berbeda dari para ilmuwan, penulis dalam pelacakan literasinya berpendapat bahwa ada lima ciri/fitur mendasar dari gerakan jihadi salafisme yaitu: tauhid, hakimiyyah, wala' wal baro', jihad, dan takfir. Kelima ciri ini dipilih berdasarkan arti pentingnya terhadap gerakan salafi-jihadi.

Jihad Salafisme merupakan istilah yang digunakan Gilles Kepel dan Kamil al-Tawil

Syaikh Idahram, Mereka memalsukan kitab-kitab karya ulama klasik,Episode kebohongan public sekte Salafi Wahabi,Cetakan ke XV(Yogyakarta : Pustaka Pesantren, 2013), 20.

${ }^{16}$ Baca lebih jauh tentang anti-Shi'ism, Guido Steinberg, "Jihadi-Salafism and the Shi'is: Remarks of the Intellectual Roots of anti-Shi 'ism” dalam Meijer, Global Salafism..., 107-125. 
yang dieksplorasi pada tahun $1998^{17}$ untuk menggambarkan gerakan salafi yang mulai mengembangkan kekerasan lewat slogan "jihad"18 selama pertengahan 1990-an. Hagghammer memaparkan bahwa istilah jihad-Salafisme pertama kali digunakan oleh New York Times pada tahun 2005, dan sebelumnya telah digunakan oleh al-Sharq al-Awsat pada tahun 1999. Terminologi ini didasarkan pada istilah yang digunakan oleh Abu Muhammad al-Maqdisi pada awal tahun 1990. Secara tertulis gerakan Salafi jihadis (al-harakah al-Jihâdiyyah asSalafiyyah) dimunculkan oleh Ayman az-Zawahiri ${ }^{19}$ dalam majalah Al-Anshar di London tahun 1994.

Menurut Kepel, Jihad Salafisme merupakan kombinasi antara penghormatan terhadap teks-teks suci dalam bentuk pemahaman yang paling literal dan komitmen berjihad melawan Amerika sebagai sasaran utamanya. Sarjana lain yang mengkaji Islam modern dalam skala global adalah Oliver Roy yang menyatakan bahwa salafisme merupakan bagian dari neofundamentalisme bersama beberapa gerakan lain seperti Hizbut Tahrir.

Sementara pada sisi yang lain, Jihad-Salafisme muncul karena terinspirasi dari pemikiran Sayyid Qutb yang membagi masyarakat ini menjadi dua: Jâhiliyyah dan Islâmiyyah. ${ }^{20}$ Umat Islam harus mengubah masyarakat jahiliah ini menjadi masyarakat yang Islami dengan menyerukan jihad melawan penguasa yang tidak melaksanakan hukum Allah. ${ }^{21}$ Meijer memberikan contoh terbaik dari gerakan Jihad-Salafisme, yakni Yusuf alUyairi yang mengombinasikan terminologi Salafi seperti tauhid, purifikasi, dan pentingnya niat yang ikhlas dengan menganalisis realitas secara kritis. Ia menyerukan jihad untuk

\footnotetext{
${ }^{17}$ Lihat Thomas Hegghammer, "Jihadi-Salafis or Revolutionaries on Religion and Politics in the study of Militant Islamism”, dalam Meijer, Global Salafim, 251-252.

18 Abul A'la al-Maududi dalam Let Us Be Muslim menjelaskan bahwa jihad tidaklah hanya melakukan sembahyang ritual tertentu saja. Menurutnya jika seseorang benar-benar mengikuti agama Islam, ia tidak dibenarkan mematuhi agama selain Islam atau mendampingkan Islam bersama-sama dengan agama lain. alMaududi meyakini bahwa tidak ada alternatif lain kecuali harus berupaya sekuat tenaga agar Islam berlaku di muka bumi. Ia menegaskan bahwa seorang muslim harus berpegang teguh pada Islam dan menyerahkan hidupnya untuk perjuangan Islam. Sependapat dengan al-Maududi, Sayyid Qutbh menyatakan bahwa jihad dalam Islam adalah jihad untuk mewujudkan uluhiah di atas muka bumi dan mengusir para thagut yang merampas kekuasaan Allah. Menurutnya jihad bertujuan untuk membebaskan manusia dari penyembahan kepada selain Allah dan dari fitnahnya dengan kekuatan keberagaman kepada Allah semata. Lebih lanjut Yusuf Qardhawi,juga memberikan pemaparan terkait dengan istilah 'jihad' berarti mencurahkan usaha (badhl al-juhd), kemampuan dan tenaga. Secara bahasa berarti menanggung kesulitan. Mengenai definisi lebih lanjut dan perbedaan jihad dan qitâl. Lihat Yusuf Qardhawi, Fiqih Jihad: Sebuah Karya Monumental Terlengkap tentang Jihad Menurut Al-Quran dan Sunnah, terj. Irfan Maulana Hakim, dkk (Bandung: Mizan, 2010), ixxv.

${ }^{19}$ Kisah hidup Ayman al- Zawahiri adalah sebagai seorang dokter bedah berbakat dan kemudian menjadi pemimpin kelompok teroris jalanan Mesir lalu menjadi orang kepercayaan Osama bin Laden. Ayman al-Zawahiri sendiri lahir pada tahun 1953 di tengah-tengah keluarga yang terpandang dan konservatif dalam beragama. Ia tumbuh besar di Maadi daerah tinggi di pinggir kota Kairoyang didiami orang-orang kaya Mesir. Kakek-kakeknya dulu adalah Rektor Universitas Al-Azhar dan presiden Universitas Kairo. Lihat lebih lanjut Lihat John L.Esposito, Unholy War: Teror in The Name Islam, (Inggris, Oxford University Press, 2002), 20.

${ }^{20}$ Lihat John L.Esposito, Unholy War: Teror in The Name Islam, (Inggris, Oxford University Press, 2002$), 72$

${ }^{21}$ Ibid, 72
} 
mengubah realitas dan menciptakan aktivis sebagaimana yang pernah dipraktikkan kalangan Leninisme. Begitu pula yang dilakukan oleh Abu Mus'ab as-Suri yang melegitimasi jihad melawan musuh karena melihat realitas yang sekuler dan besarnya pengaruh Barat terhadap generasi muda. As-Suri membentuk barisan Mujahidin dan membenarkan perilaku bom bunuh diri. Sebagaimana dijelaskan al-Rashid, kelompok Jihad-Salafisme ini merupakan konstruksi hybrida sebagai respons atas modernitas Barat yang telah memarginalkan tradisi autentik Islam.

Pemberdayaan yang dilakukan Jihad-Salafisme menggunakan propaganda secara luas, memutar klip video dan teks-teks kepada kaum muda di Barat dan Timur. Gelombang jihad semakin besar dengan menggunakan jaringan regional para ulama, seperti yang dilakukan Abu Muhammad al-Maqdisi dan al-Uyairi, yakni menggunakan internet untuk membuka situs, merekrut dan mengajak jihad global, memberikan nasihat-nasihat agama. Melalui jaringan internet, mereka mengajak melawan pemerintah yang tidak menjalankan syariat Islam. ${ }^{22}$

Assaf Moghadam menjelaskan bahwa Jihad-Salafisme adalah ideologi yang berfungsi memberikan kesadaran kepada umat muslim untuk memahami bahwa keadaan umat Islam telah mengalami kemunduran dalam bidang agama, militer, ekonomi dan budaya. Ia berusaha menciptakan identitas baru bagi penganutnya. ${ }^{23}$ Beberapa sarjana Barat menilai bahwa kaum Salafi sedang mengalami krisis identitas karena kebingungan mereka menghadapi modernitas. Jihad-Salafism menjanjikan situasi baru yang entitasnya supranasional dengan menanamkan gagasan satu, yaitu komunitas Islam global yang aman, terhormat dan tidak tertindas. ${ }^{24}$

Lebih lanjut Moghadam menjelaskan bahwa jihad-Salafisme merupakan ideologi keagamaan yang muncul karena tiga hal. Pertama, Jihad-Salafism mengilustrasikan diri dan musuhnya dengan menggunakan istilah-istilah agama, melabeli diri sebagai "tentara Muhammad", "singa Islam", atau memberi label musuhnya dengan "tentara salib", "murtad" atau "kafir". Kedua, jihad-Salafism menjelaskan strategi dan misinya sebagai salah satu ajaran agama. Mereka mengklaim bukan serangan bunuh diri, misalnya, tetapi "operasi mati syahid" dan mengklaim bahwa kaum Syi'ah adalah murtad. Ketiga, melegitimasi tindakan kekerasan

\footnotetext{
${ }^{22}$ Husain juga menceritakan bahwa pemutaran video awal tahun 1993 tentang perang di Bosnia, pembersihan serta pembantaian etnis muslim di Semenajung Balkan telah membakar semangat Jihad kaum muda di Inggris. Lihat Ed. Husein, Matinya Semangat Jihad, 100-111.

${ }^{23}$ Lihat Assaf Mughadam, Al Qaeah, Salafi Jihad, and the Diffusion of Suicide Attacks: The Globalization of Martyrdom (Baltimore, Maryland: The Johns Hopkins University Press, 2008).

${ }^{24}$ Lihat lebih lanjut Assaf Moghadam, "The Salafi-Jihad as a Religious Ideology", dalam Journal CTC Sentinel, Vol. 1, Issue 3, February 2008, 14-15.
} 
dengan referensi yang selektif dan bersumber pada Alquran dan hadis. ${ }^{25}$

Berbeda dengan kelompok Jihad-Salafisme, Nasir al-Din al- Albani dan Muqbil Hadi al-Wadi'i bukanlah kelompok takfiri, meskipun secara genealogis memiliki kaitan dengan Wahabi. Di sinilah timbul pertanyaan: apakah Salafi Jihadis bisa diterapkan pada semua gerakan Salafi? Hegghammer menegaskan bahwa terma Salafisme bersifat teologis, bukan kategori politik. ${ }^{26}$ Maka, muncullah problem ketika Salafisme dicampurkan dengan konsep jihad, sebagaimana dipahami oleh Salafi jihadis. Hegghammer menawarkan model baru yang didasarkan pada kategori analitis untuk menghindari kebingungan ini, yakni kategori politik. Jika kelompok itu memiliki kepedulian (concern) tinggi pada program politik, maka dia termasuk Jihad-Salafisme. Jika rendah, maka ia termasuk kelompok Salafi. Hal ini dapat menjawab kecenderungan berbagai pihak yang cenderung menghubungkan Salafisme dengan kekerasan.

Karena varian Salafime yang sangat beragam dan bercampur begitu rupa, Salafisme tidak mesti berkaitan dengan kekerasan. Ia mempunyai banyak tipologi. Salafisme yang selama ini dikenal dengan identitas puritan dan taat (saleh) hadir dengan berbagai orientasi: Abu Muhammad al-Maqdisi dengan orientasi ke-umat-an, al-Jama'ah al-Islamiyah Mesir dengan orientasi moral, dan Abu Mus'ab az-Zarqowi dengan orientasi sektarian. Ini berbeda dengan mereka yang berorientasi pada pembangunan politik dan nasionalisme dengan fokus bangsa dan Negara, sebagaimana diklaim oleh kelompok Ikhwân al-Muslimîn.

Hagghammer membagi bentuk Salafisme dalam dua kelompok: Salafi yang terjun pada politik praktis dan Salafi yang berpolitik dalam tataran pemikiran saja. Dalam pandangan Thariq Ramadhan, perubahan orientasi kaum Salafi dari apolitis menjadi politis dan kemudian menjadi gerakan ekstrem dalam bentuk jihad disebabkan oleh pemahaman teks.

\section{Dinamika Gerakan Jihadi-Salafisme Kontemporer}

Al-Qaida dalam mewujudkan Negara Islam, mengidentifikasi dengan sebuah gerakan dalam pemikiran politik Islam yang dikenal sebagai Jihadi-Salafisme, atau jihadisme singkatnya. Pemimpin kelompok secara eksplisit mematuhi gerakan ini. Sebagai contoh, dalam pidato audio tahun 2007, pemimpin negara Islam Abu 'Umar al-Baghdadi mengajukan banding "kepada kelompok Sunni, dan kepada para pemuda Jihadi-Salafisme (al-Salafiyyah al-

\footnotetext{
${ }^{25}$ Ibid, 15-16 dan 257-263.

${ }^{26}$ Meijer, Global Salafism, 27.
} 
Jihadiyya) khususnya, di seberang seluruh dunia". ${ }^{27}$ Pada tahun yang sama, wakilnya mendeklarasikan Negara Islam sebagai bagian dari "arus Jihadi-Salafisme."28

Jihadi-Salafisme adalah gerakan ideologis yang berbeda dalam Islam Sunni. Ini mencakup jaringan global ilmuwan, situs web, media, dan, yang terakhir, pendukung yang tak terhitung jumlahnya di media sosial. ${ }^{29}$ Gerakan ini didasarkan pada pembacaan ekstremis dan minoritas kitab suci Islam yang juga secara tekstual ketat, berakar kuat dalam tradisi teologis pramodern, dan secara luas diuraikan oleh kader agama yang diakui.

Dua aliran pemikiran Islam sangat berkontribusi pada munculnya sekolah jihad di abad ke 20. Yang pertama dikaitkan dengan Ikhwanul Muslimin di Mesir. ${ }^{30}$ Ikhwanul Muslimin dalam kemunculanyamemperjuangkan penyelamatan kekhalifahan sebagai sistem pemerintahan yang ideal untuk dunia Islam, sebuah tema populer di awal abad ke-20. Dengan hilangnya kekhalifahan Utsmaniyah pada tahun 1924, berbagai pemimpin dan kelompok Muslim di seluruh dunia, mulai dari Afrika Utara hingga Arab sampai Asia Tenggara, menyerukan pembenahan kembali kekhalifahan. Namun, penekanan Ikhwanul Muslimin tentang khilafah sangat penting, karena para ideolog dan kelompok jihad pertama muncul sebagai serpihan radikal dari Ikhwan. Ambisi Jihadi untuk menghidupkan kembali kekhalifahan tampaknya berasal dari Ikhwanul Muslimin.

Pendiri Persaudaraan berbicara panjang lebar tentang khilafah. Sebagaimana penulis kutip: The Brotherhood's founder spoke at length of the caliphate. In one instance he remarked: "Islam requires that the Muslim community unite around one leader or one head, the head of the Islamic State, and it forbids the Mus- lim community from being divided among states..." Elsewhere Banna commented: "The Muslim Brotherhood puts the idea of the ca-liphate and work to restore it at the forefront of its plans. ${ }^{31}$

Namun dalam praktiknya, seperti yang telah dicatat oleh para sejarawan, Persaudaraan menunjukkan "relatif ketidakpedulian" untuk benar-benar memulihkan kekhalifahan. Membangun liputan lebih merupakan tujuan jangka panjang daripada tujuan yang menengahi. Banna sendiri mengakui bahwa pencapaian tujuan ini akan membutuhkan kerja keras yang

\footnotetext{
27 Abu 'Umar al-Baghdadī, “Wa-in tantahū fa-huwa khayr lakum,” Mu'assasat al-Furqān, 8 July 2007. Transcript in Majmu' ', 26-35

${ }_{28}$ Abu H amza al-Muhājir, "Qul mūtū bi-ghayzikum,” Mu'assasat al-Furqān, 5 May 2007. Transcript in Majmū', 147-152.

${ }^{29}$ Lihat Cole Bunzel dalam paper state Chaliphete: The Idiology of The Islamic State, No 19, Maret 2017, 7

${ }^{30}$ Didirikan pada tahun 1928 oleh Hasan al-Banna sebagai gerakan politik yang bertekad untuk memenangkan kekuasaan dan pengaruh di masyarakat dalam melawan Negara. Ikhwanul Muslimin tidak pernah sama sekali doktrinnya seperti jihadis masa kini. Ikhwanul Muslimin adalah gerakan Sunni yang eksklusif, namun tidak memusuhi sekte Islam lainnya, seperti Syi'isme, atau orientasinya, seperti mistisisme sufi. Gerakan tersebut muncul sebagai tanggapan terhadap bangkitnya imperialisme Barat dan kemunduran Islam yang terkait dalam kehidupan publik, tren yang ingin dibalikkan melalui aktivisme Islam akar rumput.

${ }^{31}$ Cole Bunzel dalam paper state Chaliphete: The Idiology of The Islamic State,... 8
} 
signifikan, termasuk mengadakan konferensi dan membentuk partai politik dan aliansi di seluruh dunia Islam. Meskipun demikian, pembicaraan idealistik akan terus ditampilkan dalam pernyataan Persaudaraan, dan terkadang masih keluar. Baru-baru ini seperti tahun 2012, Panduan Ikhwanul Muslimin berbicara tentang membangun kembali "Negara Muslim." ${ }^{32}$

Aliran pemikiran Islam yang kedua yang menyumbang pada ideologi Negara Islam dikenal sebagai Salafisme, sebuah gerakan teologis terutama dalam Islam Sunni yang berkaitan dengan pemurnian iman. Salafisme berfokus untuk menghilangkan penyembahan berhala (syirik) dan menegaskan keesaan Tuhan (tawhid). ${ }^{33}$ Silsilah intelektual Salafi yang khas meluas sampai abad pertengahan. Tulisan-tulisan ulama' Hanbali dari Suriah Ibn Taymiyya (wafat tahun 1328) dan murid-muridnya memberikan inti teologis Salafi. Kemudian pemikir Salafi yang signifikan berasal dari gerakan Wahhabi, atau Wahhabisme, sebuah subset dari Salafisme yang didirikan di Jazirah Arab oleh Muhammad ibn 'Abd al-Wahhab (wafat tahun 1792). Pada Wahhabisme 1967 yang ke-18 dikawinkan dengan pendirian politik Saudi, dan tetap seperti sekarang ini. The Sau- dis membantu kaum Wahhabi untuk memaksakan versi iman mereka ke seluruh Arab dengan melakukan jihad melawan orang-orang yang dianggap sesat demi menghilangkan syirik dan menguatkan tawhid. Jihad Wahhabi melibatkan penghancuran makam dan tempat suci dan penegakan praktik ritual yang tepat, serta pembersihan Islam Syi'isme. $^{34}$

Pada dekade-dekade abad ke-20, Arab Timur Tengah melihat bangkitnya kelompokkelompok Islam yang keras yang dipengaruhi oleh aktivisme Ikhwanul Muslimin dan eksklusivisme Salafi. Kelompok-kelompok ini, termasuk Jamaah Islam Mesir dan Kelompok Islam, di Mesir, dan Kelompok Islam Bersenjata dan Kelompok Salafi untuk Khotbah dan Pertarungan, di Aljazair, adalah pelopor kelompok Jihad-Salafi hari ini. Secara ideologis,

\footnotetext{
32 Ibid, 9

${ }^{33}$ Salafis memandang diri mereka sebagai satu-satunya Muslim sejati, mengingat mereka yang mempraktikkan apa yang disebut "penyembahan berhala utama" berada di luar batas-batas Islam. iman. Mereka yang menyembah - atau dianggap mempermalukan - batu, orang suci, makam, dll, dianggap murtad, desertir agama. Ini mencakup kaum Syiah dan, bagi banyak Salafi, demokrat, atau mereka yang berpartisipasi dalam sistem demokrasi. Kaum Syiah bersalah karena syirik karena rasa hormat mereka terhadap keluarga Nabi Muhammad, antara lain, sementara kaum demokrat berbuat salah dalam menugaskan "pasangan" kepada Tuhan dalam peraturan perundang-undangan, dianggap hak prerogatif dari Perundang-undangan Ilahi.

${ }^{34}$ Elemen anti-Syi'ah dalam jihadisme berasal dari animisme historis Salafisme terhadap kaum Syiah. Pada tahun 1792, misalnya, pasukan Saudi Wahhabi melancarkan serangan ke pusat al-Ahsa Syiah di Arabia timur di untuk membasmi praktik Syiah di sana.Kemudian, pada tahun 1801, mereka mengepung dua kota suci Syi'ah di Najaf dan Karbala di Irak, menjarah Karbala dan membunuh beberapa orang di sana. Pada akhir 1927, cendekiawan Wahhabi terkemuka di kerajaan Saudi berusaha secara paksa untuk "mengubah" kaum Syi'ah dari provokasi timur negara itu atau mengusir mereka.Kerajaan Arab Saudi modern tidak lagi secara aktif menuntut perang anti-Syiah; Sentimen anti-Syi'ah masih berjalan dalam Salafisme.
} 
inspirasinya yang utama adalah Sayyid Qutb, ${ }^{35}$ seorang ideolog Persaudaraan Muslim Mesir yang produktif yang menganjurkan versi revolusioner aktivisme Persaudaraan yang revolusioner. ${ }^{36}$ Kelompok-kelompok ini bertujuan untuk menggulingkan pemerintah yang telah mapan dan menggantinya dengan negara-negara Islam. Al-Qaeda memiliki ideologi serupa namun menganjurkan strategi yang berbeda, dengan fokus menyerang Amerika Serikat sebagai langkah awal untuk menciptakan sebuah negara Islam di Timur Tengah. Pemimpin Al-Qaeda, Osama Bin Laden, sering berbicara tentang mengembalikan kekhalifahan. ${ }^{37}$

Seiring dengan bangkitnya kelompok-kelompok ini, juga muncul jaringan sarjana independen yang longgar yang memberi bahan ideologis pada gerakan jihad yang muncul. Karya-karya para ilmuwan seperti Abu Muhammad al-Maqdisi-Jordania dan Abu Basir alTartusi Suriah membantu mengatur nada gerakan. Mempengaruhi lebih banyak oleh Qutb dan Persaudaraan sejak dini, para ilmuwan ini secara bertahap menjauhkan diri darinya dan mengadopsi orientasi Salafi yang lebih banyak. Fokus mereka pada aspek Salafisme yang lebih kejam melahirkan Jihadi-Salafisme.

Dalam 20 tahun terakhir, jihadisme telah semakin dominan didominasi oleh dimensi Salafi. Akibatnya, penulis Ikhwanul Muslimin, yang menurut Salafis tidak mematuhi teologi yang tepat, jarang dikutip atau dirujuk oleh jihadis modern. Sebaliknya, karya Ibn Taymiyyah dan para ilmuwan tradisi Wahhabi telah menjadi tulang punggung ideologis gerakan tersebut. ${ }^{38}$

Jika jihadisme ditempatkan pada spekulasi politik, al-Qaeda akan menjadi negara kirinya dan negara Islam yang haknya. Pada prinsipnya, kedua kelompok mematuhi teologi Salafi dan mencontohkan karakter Salafi yang semakin Salafi dari gerakan jihad. Tapi Negara Islam melakukannya dengan tingkat keparahan yang lebih tinggi. Berbeda dengan al-Qaeda, ini benar-benar tanpa kompromi mengenai hal-hal mendasar, memprioritaskan promosi perpecahan pemikiran Salafi yang tidak memaafkan.

Pengadopsian Islam dari versi Jihadi-Salafisme yang sangat parah ini disebabkan oleh Abu Mus'ab al-Zarqawi, pendiri al-Qaeda di Irak yang mempelajari teologi dengan ilmuwan jihad terkemuka, Abu Muhammad al-Maqdisi. Pemimpin pertama Negara Islam, Abu 'Umar

\footnotetext{
${ }^{35}$ Sayyid Qutb memiliki nama lengkap Sayyid Qutb Ibrahim Husayn Shadhili, lahir pada tahun 1906 di sebuah desa bernama Musha. Secara administratif, Musha berada di provinsi Asyut Mesir (Mudiriyyat Asyut) dan secara geografis merupakan bagian dari Sa'id, jalur sempit yang dibatasi oleh dataran tinggi padang pasir, yang mengikuti jalannya Sungai Nil dari Aswan sampai dekat pangkalan Delta. Lihat lebih lanjut John Calvret, Sayyid Qutb and the Origin of Radical Islamism, New York: Oxford University Press, 2013, 25.

${ }^{36}$ Lihat John L.Esposito, Unholy War: Teror in The Name Islam, 68.

${ }^{37}$ Ibid, 81.

${ }^{38}$ Ibid
} 
al-Baghdadi dan Abu Hamza al-Muhajir, juga pendukung Jihadi-Salafi. Pidato mereka menarik banyak otoritas Salafi yang telah terbit, banyak dari mereka berasal dari tradisi Wahhabi. Jurubicara resmi saat ini dari Negara Islam, Abu Muhammad al-'Adnani, bahkan mengajarkan tulisan-tulisan Muhammad ibn 'Abd al-Wahhab kepada sesama jihadis. Dokumentasi Wakil Presiden Negara Islam dari Agustus 2014 menunjukkan sebuah van pemberitaan resmi di Raqqa, Syria diplester dengan katekismus Wahhabi. Beberapa publikasi resmi dari Negara Islam hanya sedikit dari kutipan panjang dari para ilmuwan Wahhabi. ${ }^{39}$

Pendekatan kelompok terhadap doktrin jihad juga memiliki jejak Salafi yang jelas. Secara tradisional, ji-hadis, termasuk yang di al-Qaeda, telah mendukung "jihad defensif," melakukan tindakan militan mereka secara deensif. Mereka melihat Timur Tengah diserang oleh penguasa "murtad" sekuler dan pendukung "pejuang" Barat mereka. . Negara Islam juga menganjurkan "jihad defensif." Seperti mantan Is-Pemimpin negara Islam Abu 'Umar alBaghdadi pernah mengatakan, "Para penguasa tanah Muslim adalah pengkhianat, orang yang tidak beriman, pendosa, pendusta, penyesat, dan penjahat." Terlebih lagi, katanya pada tahun 2007, "kita percaya bahwa melawan mereka adalah kebutuhan yang lebih besar daripada melawan tentara pendudukan. "

Negara Islam juga menekankan bentuk jihad yang menyinggung, yang dalam tradisi Wahhabi didasarkan pada pencabutan syirik, penyembahan berhala, di mana pun ditemukan. Misalnya, dalam sebuah pidato di tahun 2007 Abu 'Umar al-Baghdadi mengutip seorang Wahabi sarjana yang bertekad untuk tujuan jihad: "Berakhirnya pertempuran melawan orangorang kafir mengarah bukanlah penyembah berhala (musyrik) yang tersisa di dunia ini." 40 Dalam pidato lain, Baghdadi secara eksplisit menekankan pentingnya "jihad ofensif," yang dia didefinisikan sebagai "mengejar orang-orang kafir yang murtad dengan menyerang mereka masuk wilayah rumah mereka, untuk membuat firman Tuhan paling tinggi dan sampai tidak ada penganiayaan. "Konsisten dengan ajaran Wahhabi," penganiayaan "tidak dapat berarti penyembahan berhala.

"Jihad ofensif" negara Islam diarahkan terutama terhadap Syi'ah di kawasan itu. Terlepas dari kenyataan, persepsi bahwa kaum Syi'ah memiliki desain ekspansi di Timur

\footnotetext{
${ }^{39}$ Teks dan pidato Negara Islam menekankan sejumlah konsep doktrinal. Yang paling menonjol dari ketentuan ini: semua Muslim harus berasosiasi secara eksklusif dengan sesama Muslim "sejati" dan melepaskan diri dari orang yang tidak sesuai dengan definisi sempit ini; Kegagalan untuk memerintah sesuai dengan hukum Tuhan merupakan ketidakpercayaan; memerangi negara Islam sama saja dengan kemurtadan; Semua Muslim Syi'ah murtad layak mati; dan Ikhwanul Muslimin dan Hamas adalah pengkhianat terhadap Islam, di antara banyak hal lainnya. Yang penting, Islamic State menyandang konsep-konsep ini dalam literatur tradisional Salafi, dan lebih dogmatis tentang penerapannya daripada al-Qaeda

${ }^{40}$ Cole Bunzel dalam paper state Chaliphete: The Idiology of The Islamic State,... 10
} 
Tengah yang mengharuskan mereka melawan mereka. Proyek Syi'ah, jadi diyakini, bertujuan sebuah "bulan sabit Syi'ah yang membentang dari Teheran ke Bei- rut." Republik Islam Iran, Hizbullah di Lebanon, dan rezim Asad di Suriah semuanya merupakan bagian dari "bulan sabit" ini. Para pemimpin Iran bertujuan untuk "mengubah Irak menjadi sebuah negara Syiah, "dan Amerika Serikat terlibat dalam rencana mereka. Menurut Negara Islam, transisi sejarah Irak baru-baru ini dari seorang Sunni ke mayoritas Syi'ah adalah bukti adanya" Shi'itisasi yang menyeramkan . "Sebagaimana Abu Bakar Umar al-Baghdadi pernah menegaskan, baru dalam 50 sampai 70 tahun terakhir, Sunni beralih ke Syiah dimulai. Sebelumnya, Irak adalah negara Sunni. Secara terpisah, al-Qaeda dan negara Islam sama-sama menekankan kebutuhan untuk mengembalikan kekhalifahan, meskipun bertentangan dengan apakah negara Islam telah benarbenar melakukan ini.

Para ilmuwan jihad terkemuka, meski memiliki keteguhan Salafi sendiri, cenderung berpihak pada al-Qaeda mengenai Negara Islam dalam perseteruan yang berkembang antara dua kelompok tersebut. Hal ini sebagian karena kesetiaan mereka kepada al-Qaeda dan kepemimpinan seniornya. Cendekiawan jihad pro-Qaeda juga keberatan dengan kecenderungan Negara Islam terhadap kekerasan ekstrem dan sewenang-wenang, termasuk pemancungan yang mengerikan, dan kelebihan yang dirasakan dalam praktik takfir, atau menyatakan bahwa orang Muslim lainnya adalah orang-orang kafir.

Negara Islam, bagaimanapun, mempertahankan otoritas ilmiahnya sendiri, sebagian besar diambil dari generasi muda. Yang paling menonjol (dan mungkin paling berpengaruh) dari para ilmuwan ini adalah Bahrain Manu yang berusia 30 tahun al-Bin'ali. Mantan murid Abu Muhammad al-Maqdisi, Bin'ali sekarang adalah seorang sarjana Negara Islam yang residen dan dikabarkan menjadi seorang otoritas puncak.

Pada pertengahan 2014, setelah jatuh dengan mantan mentornya atas perseteruan Negara Islam dengan al-Qaeda, Bin'ali menulis sebuah sanggahan sombong dari gurunya. Bin'ali membandingkan penolakan Maqdisi terhadap Negara Islam tersebut kepada seorang ilmuwan Yaman yang terkenal pada abad ke 18 yang menolak gerakan Wahabi awal di Arabia.Orang Yaman ini awalnya menyambut negara Wahhabi muda, hanya untuk mencela itu atas rumor kelebihan dalam kekerasan dan takfir. DenganPoin Bin'ali dalam menarik perbandingan ini jelas: dari sudut pandangnya, Negara Islam adalah seperti negara Wahhabi awal sebelumnya - penjaga sejati warisan Salafi-Wahhabi. Percaya diri dalam peran ini, ia tidak akan pernah melepaskan misi ilahi-nya. Jihadis yang gagal mendukung Negara Islam hanya berada di sisi sejarah yang salah. alasan yang sama, Bin'ali mengeluh, bahwa Maqdisi telah 
mengecam negara Islam tersebut. ${ }^{41}$

\section{E. Catatan Akhir}

Kata Salafi adalah sebuah bentuk penisbatan al-salaf al-salih, yaitu tiga genarasi pertama Muslim yang dipandang sebagai uswah bagi masa depan umat Islam. Kata as-salaf secara bahasa juga bermakna orang-orang yang mendahului atau hidup sebelum zaman kita. Islam. Bernard Haykel mengemukakan bahwa Salafism mereferensi pada Ahl al-Hadith sejak masa kekhilafahan Abbasiyah, yang mengkosentrasikan pada studi hadis dengan maksud untuk membersihkan Islam dari campur tangan non-muslim. Sebagai gerakan pemurnian Islam, Salafism mengajarkan untuk kembali kepada sumber-sumber pokoknya, yakni al-Qur'an dan Hadis. Tokoh-tokoh Salafism adalah: Ahmad bin Hanbal, Taqiy al-Din ibn Taymiyah, dan dipertegas dalam Wahhabism oleh 'Muhammad ibn 'Abd al-Wahhab.

Jihad Salafisme merupakan istilah yang digunakan Gilles Kepel dan Kamil al-Tawil yang dieksplorasi pada tahun 1998 untuk menggambarkan gerakan salafi yang mulai mengembangkan kekerasan lewat slogan "jihad" selama pertengahan 1990-an. Hagghammer memaparkan bahwa istilah jihad-Salafisme pertama kali digunakan oleh New York Times pada tahun 2005, dan sebelumnya telah digunakan oleh al-Sharq al-Awsat pada tahun 1999. Terminologi ini didasarkan pada istilah yang digunakan oleh Abu Muhammad al-Maqdisi pada awal tahun 1990. Secara tertulis gerakan Salafi jihadis (al-harakah al- Jihadiyyah asSalafiyyah) dimunculkan oleh Ayman az-Zawahiri.

Dua aliran pemikiran Islam sangat berkontribusi pada munculnya sekolah jihad di abad ke 20. Yang pertama dikaitkan dengan Ikhwanul Muslimin di Mesir. Ikhwanul Muslimin dalam kemunculanya memperjuangkan penyelamatan kekhalifahan sebagai sistem pemerintahan yang ideal untuk dunia Islam, sebuah tema populer di awal abad ke-20. Aliran pemikiran Islam yang kedua yang menyumbang pada ideologi Negara Islam dikenal sebagai Salafisme, sebuah gerakan teologis terutama dalam Islam Sunni yang berkaitan dengan pemurnian iman. Salafisme berfokus untuk menghilangkan penyembahan berhala (syirik) dan menegaskan keesaan Tuhan (tawhid).

\footnotetext{
${ }^{41}$ Cole Bunzel dalam paper state Chaliphete: The Idiology of The Islamic State,...11
} 


\section{Sumber Rujukan}

Bunzel, Cole dalam paper state Chaliphete: The Idiology of The Islamic State, No 19, Maret 2017

Commins, Davit, The Wahabi Mission and Saudi Arabia, London: I.B. tauris, 2006

Calvret, John Sayyid Qutb and the Origin of Radical Islamism, New York: Oxford University Press, 2013

El-Fadl, Khaled M.Abou, Selamatkan Islam dari Muslim Puritan, terj. Helmi Mustofa, Jakarta: Serambi Ilmu Semesta,2006.

Esposito, John, Unholy War: Teror in The Name Islam, (Inggris, Oxford University Press, 2002

Haykel, Bernald. Revival and Reform in Islam: The Legacy of Muhammad al-Shawkani. Cambridge: Cambridge University Press. 2003

Husain, ED. The Islamist. London: Penguin Books. 2007

Hanafi, Hasan , Muqoddimah fi' ilmi al-Istighrab, 1999, atau dalam terjemahanya Pengantar Oksidentalisme: Sikap Kita Terhadap Barat, Jakarta Paramadina, 2000.

Hegghammer, Thomas"Jihadi Salafis or Revolutionaries: On Religion and Politics in the Study of Islamist Militancy", dalam R Meijer (ed), Global Salafism: Islam's New Religious Movement, London/New York: Hurst/Columbia University Press, 2009

Idahram, Syaikh, Mereka memalsukan kitab-kitab karya ulama klasik,Episode kebohongan public sekte Salafi Wahabi,Cetakan ke XV.Yogyakarta : Pustaka Pesantren, 2013.

Jaenuri, Jaenuri, Radikalisme dan Terorisme, Akar Ideologi dan Tuntutan Aksi, Malang: Intrans Publishing, 2016

Mughadam, Assaf, Al Qaeah, Salafi Jihad, and the Diffusion of Suicide Attacks: The Globalization of Martyrdom, Baltimore, Maryland: The Johns Hopkins University Press, 2008

Meijer, Roel, Global Salafism: Islam's New Religious Movement . London: C. Hurst Company, 2009

Moghadam, Assaf "The Salafi-Jihad as a Religious Ideology", dalam Journal CTC Sentinel, Vol. 1, Issue 3, February 2008 
Stephane Lacroix, "Between Revolution and Apoliticsm: Nasir al-Din al-Albani and his Impact on the Shaping of the Contemporary Salafism” dalam Meijer, Global Salafism...,

Steinberg, Guide "Jihadi-Salafism and the Shi'is: Remarks of the Intellectual Roots of antiShi'ism” dalam Meijer, Global Salafism

Qardhawi, Yusuf. Fiqih Jihad: Sebuah Karya Monumental Terlengkap tentang Jihad Menurut Al-Quran dan Sunnah, terj. Irfan Maulana Hakim, dkk. Bandung: Mizan, 2010. 